Ann. Biol. anim. Bioch. Biophys., 1978, 18 (2A), 283-286.

\title{
Effect of cold shock on enzyme release in buffalo (Bubalus bubalis) spermatozoa
}

par K. S. SIDHU, S. S. GURAYA

Department of Zoology, College of Basic Sciences and Humanities Punjab Agricultural University, Ludhiana, Punjab, India

Summary. We have studied the effect of cold shock on the percentage of enzyme release in buffalo spermatozoa, i.e. alcohol, malic, glucose-6-phosphate, isocitric, lactate, sorbital dehydrogenases, glutamic oxaloacetic transaminase (GOT), glutamic pyruvic transaminase (GPT), hyaluronidase, arylsulphatase A and arylsulphatase B. Significant amounts of alcohol, malic and sorbital dehydrogenases, GOT, hyaluronidase, arylsulphatase A and arylsulphatase B were liberated; glucose-6-phosphate, isocitric, lactate dehydrogenase and GPT were not affected by cold shock.

\section{Introduction.}

Relatively little work has been carried out previously to determine the release of intracellular enzymes from spermatozoa after cold shock. Mann (1951) reported the release of cytochrome $C$ and other intracellular proteins from spermatozoa into extracellular media. The release of GOT and GPT from spermatozoa with cold shock has been considered to be an index of measurement of cellular injury (Graham and Pace, 1967 ; Roychaudhury, Pareek and Gowda, 1974). To the best of our knowledge, the effect of cold shock on dehydrogenases, aminotransferases and hydrolases have not been studied in buffalo spermatozoa. This paper reports our results on the subject.

\section{Material and methods.}

Semen samples (6 to 10 ejaculates) were collected from buffalo bulls (Bubalus bubalis) of proven fertility and maintained at $37^{\circ} \mathrm{C}$ during transport to the laboratory. Only semen samples of good motility and count were used. Each semen sample was divided into two equal parts - one for control and the other for experimentation. The control sample was maintained at $30^{\circ} \mathrm{C}$, while the experimental one was subjected to cold shock according to the method of Harrison and White (1972). Live/dead count was estimated both in control and experimental samples by the method of Hancock (1952). After cold shock, both samples (control and experimental) were centrifuged at $2000 \mathrm{rpm}$ for $20 \mathrm{~min}$ at $4^{\circ} \mathrm{C}$. A centrifuging temperature of $4^{\circ} \mathrm{C}$ was consi- 
dered as sufficiently high to avoid the release of enzymes (except for a partial release of hyaluronidase), but low enough to check their denaturation. The dehydrogenases were estimated in supernatants by measuring the density increase with reduction of coenzymes NAD/NADP at $340 \mathrm{~m} \mu$, as cited in Colowick and Kaplan (1955). The protein in each sample was estimated by the method of Lowry ef al. (1951). Enzyme activity is expressed in units per $\mathrm{mg}$ of protein (specific activity). Units of alcohol dehydrogenase are expressed as an increase in density of 0.045 per $3 \mathrm{~min}$, while those of malic, glucose-6-phosphate, isocitric, lactate and sorbital dehydrogenases are shown as an increase in density of 0.01 per min. GOT and GPT were analyzed according to the method of Reitman and Frankel $(1956,1957)$ as cited in Bergmeyer (1974). The enzyme activity has been indicated by microunits per milliliter. Hyaluronidase was estimated according to the method of Linker as cited in Bergmeyer (1974). Arylsulphatase $A$ and $B$ were estimated according to the method of Baum as cited in King (1961). A unit of hyaluronidase was defined as $\mu$ moles of $\mathrm{N}$-acetyglucosamine released per min per $\mathrm{ml}$ at $37{ }^{\circ} \mathrm{C}$, while a unit of arylsulphatase $A$ and $B$ was defined as $m \mu$ moles of 4-nitrocatechol release per min per $\mathrm{ml}$ at $37^{\circ} \mathrm{C}$.

\section{Results.}

The percentage of the various enzymes released is given in table 1 . Cold shock caused the significant liberation of alcohol, malate and sorbital dehydrogenases from

\section{TABLE 1}

Percentages of enzymes released in the media after cold shock in buffalo spermatozoa

\begin{tabular}{|c|c|c|c|c|}
\hline \multirow[b]{2}{*}{ Enzymes } & \multicolumn{4}{|c|}{ Units of enzymes in } \\
\hline & $\begin{array}{c}\text { Whole sperm } \\
\text { sonicate } \\
\text { U }\end{array}$ & $\begin{array}{l}\text { Intact } \\
\text { sperm } \\
\mathbf{u}\end{array}$ & $\begin{array}{l}\text { Cold shocked } \\
\text { sperm } \\
\text { ú }\end{array}$ & $\begin{array}{l}\text { Percentage of } \\
\text { enzyme release } \\
\frac{\dot{u}-u}{U-u} \times 100\end{array}$ \\
\hline \multicolumn{5}{|l|}{ Dehydrogenoses } \\
\hline $\begin{array}{l}\text { Alcohol dehydrogenase } \ldots \ldots \ldots \ldots \\
\text { Malate dehydrogenase ........... } \\
\text { Glucose-6-phosphate-dehydroge- }\end{array}$ & $\begin{array}{l}0.31 \\
0.97\end{array}$ & $\begin{array}{l}0.123 \\
0.042\end{array}$ & $\begin{array}{l}0.28 \\
0.152\end{array}$ & $\begin{array}{r}83.05 \\
4.56\end{array}$ \\
\hline $\begin{array}{l}\text { nase } \ldots \ldots \ldots \ldots \\
\text { Isocitric dehydrogenase } \ldots \ldots \ldots \ldots \\
\text { Lactate dehydrogenase } \ldots \ldots \ldots \ldots \\
\text { Sorbital dehydrogenase } \ldots \ldots \ldots \ldots\end{array}$ & $\begin{array}{l}10.248 \\
22.396 \\
10.7830 \\
1.21\end{array}$ & $\begin{array}{l}0.66 \\
0.99 \\
0.0934 \\
0.19\end{array}$ & $\begin{array}{l}0.68 \\
1.20 \\
0.110 \\
0.365\end{array}$ & $\begin{array}{r}0.19 \\
0.26 \\
0.15 \\
17.18\end{array}$ \\
\hline \multicolumn{5}{|l|}{ Aminotransferases } \\
\hline $\begin{array}{l}\text { Glutamic oxalo acetic transaminase } \\
\text { Glutamic pyruvic transaminase... }\end{array}$ & $\begin{array}{r}5.23 \\
12.57\end{array}$ & $\begin{array}{l}0.800 \\
1.16\end{array}$ & $\begin{array}{l}4.284 \\
1.13\end{array}$ & $\begin{array}{r}78.56 \\
0.01\end{array}$ \\
\hline \multicolumn{5}{|l|}{ Hydroloses } \\
\hline $\begin{array}{l}\text { Hyaluronidase } \ldots \ldots \ldots \ldots \ldots \ldots \\
\text { Aryl sulphatase } A \ldots \ldots \ldots \ldots \ldots \\
\text { Aryl sulphatase } B \ldots \ldots \ldots \ldots \ldots \ldots\end{array}$ & $\begin{array}{l}0.096 \\
6.682 \\
2.097\end{array}$ & $\begin{array}{l}0.016 \\
4.280 \\
0.616\end{array}$ & $\begin{array}{l}0.028 \\
6.328 \\
1.59\end{array}$ & $\begin{array}{l}14.64 \\
85.26 \\
65.77\end{array}$ \\
\hline
\end{tabular}


the buffalo spermatozoa. Release of alcohol dehydrogenase was highest ( 83.05 p. 100) followed by sorbital dehydrogenase (17.18 p. 100) and malate dehydrogenase (4.56 p. $100)$ in decreasing order. Glucose-6-phosphate, isocitric and lactate dehydrogenases were not affected. Cold shock also caused the liberation of hyaluronidase, arylsulphatase A, arylsulphatase B and GOT, whereas GPT remained intact. These enzymes could be arranged in the decreasing order of release, i.e. arylsulphatase $A(85.26$ p. 100), GOT (78.56 p. 100), arylsulphatase B (65.77 p. 100) and hyaluronidase (14.64 p. 100). Cold shock also increases the percentage of dead sperm (20 p. 100).

\section{Discussion.}

The present study has clearly revealed that cold shock of buffalo spermatozoa causes the release of alcohol, malic and sorbital dehydrogenases, GOT, hyaluronidase and arylsulphatase A and B, but does not affect glucose-6-phosphate, isocitric, lactate dehydrogenases and GPT. The percentage of the various enzymes released varies greatly (table 1). Mann (1951) reported slow release of cytochrome $C$ from spermatozoa into extracellular media. The release of GOT and GPT from bull and ram spermatozoa with cold shock has been reported (Pace and Graham, 1970 ; Graham, Crabo and Schmehl, 1973 ; Roychaudhury ef al., 1974). Species release differences (Roychaudhury ef al., 1974) have been attributed to intrinsic divergencies in the cells (White and Wales, 1960).

Quinn et al. (1969) have indicated the release of acrosomal material consisting of protein, non-dialyzable phosphorus and polysaccharides into extracellular media with cold shock and freezing. The presence of hyaluronidase, arylsulphatase $A$ and arylsulphatase $B$ in the extracellular media after cold shock in the buffalo can be attributed to the detached acrosomes observed by Guraya and Sidhu (1977). Acrosome detachment with cold shock has also been reported in other farm animals (Hancock, 1952 ; lype et al., 1963 ; Quinn ef al., 1969).

Reçu en sepiembre 1977.

Accepté en décembre 1977.

Résumé. Nous avons étudié l'effet d'un refroidissement brutal sur la libération des enzymes du spermatozoide de Buffle, notamment les déshydrogénases alcoolique, malique, glucoso-6-phosphate, isocitrique, lactique et sorbitique, les transaminases oxalacétoglutamique (GOT), pyruvo-glutamique (GPT), la hyaluronidase ef les arylsulfatases A et B.

Des quantités significatives de déshydrogénases alcoolique, malique et sorbitique, de GOT, de hyaluronidase et des arylsulfatases A et B sont libérées. Seules les déshydrogénases glucoso-6-phosphatase, isocitrique ef lactique, ainsi que la GPT ne sont pas affectées.

\section{Références}

BERGMEYER H. U., 1974. Method of enzymatic analysis, vol. 2, Acad. Press, London. COLOWICK S. P., KAPLAN N. O., 1955. Methods in enzymology. Acad. Press, New York. GRAHAM E. F., PACE M. M., 1967. Some biochemical changes in spermatozoa due to freezing. Cryobiology, 4, 75-78.

GRAHAM E. F., CRABO B. G., SCHMEHL M. K. L., 1973. Utilization of enzyme assay in developing technique for freezing semen. Proc. 8th Inter. Zootec. Symp., Milan, 95. 
GURAYA S. S., SIDHU K. S., 1977. Histochemical observations of buffalo spermatozoa. Ind. J. Anim. Sci., 45, 923-928.

HANCOCK J. L., 1952. The morphology of bull spermatozoa. J. exp. Biol., 29, 445-453.

HARRISON R. A. P., WHITE I. G., 1972. Glycolytic enzymes in the spermatozoa and cytoplasmic droplets of bull, boar and ram and their leakage after shock. J. Reprod. Fert., 30, 105-115.

IYPE P. T., ABRAHAM K. A., BARGAVA P. M., 1963. Further evidence for a positive role of the acrosome in the uptake of labelled amino acids by bovine and avian spermatozoa. J. Reprod. Fert., 5, 151-155.

KING E. J., 1961. Microanalysis in medical biochemistry. J. A. Churchill Ltd. London.

LOWRY O. H., ROSENBROUGH N. J., FARR A., RANDALL R. J., 1951. Protein measurement with the folin phenol reagents. J. biol. Chem., 193, 265-275.

MANN T., 1951. Studies on the metabolism of semen (7) cytochrome in human spermatozoa. Biochem. J., 48, 386-388.

PACE M. M., GRAHAM E. F., 1970. The release of glutamic oxaloacetic transaminase from bovine spermatozoa as a test method of assessing semen quality and fertility. Biol. Reprod., 3, 140-144.

QUINN P. J., WHITE I. G., CLELAND K. W., 1969. Chemical and ultrastructural changes in ram spermatozoa after washing, cold shock and freezing. J. Reprod. Fert., 18, 209-222.

ROYCHAUDHURY P. N., PAREEK P. K., GOWDA H. C., 1974. Effect of cold shock on glutamic oxaloacetic transaminase (GOT) and glutamic pyruvic transaminase (GPT) release from bull and ram spermatozoa. Andrologia, 4, 315-319.

WHITE I. G., WALES R. G., 1960. The susceptibility of spermatozoa to cold shock. Int. J. Fert., 5, 195-197. 